\title{
Frontline robots in tourism and hospitality: service enhancement or cost reduction?
}

\author{
Daniel Belanche $^{1}$ (D) $\cdot$ Luis V. Casaló ${ }^{2}$ (D) $\cdot$ Carlos Flavián $^{1}$ \\ Received: 16 March 2020 / Accepted: 14 July 2020 / Published online: 29 July 2020 \\ (C) The Author(s) 2020
}

\begin{abstract}
Robots are being implemented in many frontline services, from waiter robots in restaurants to robotic concierges in hotels. A growing number of firms in hospitality and tourism industries introduce service robots to reduce their operational costs and to provide customers with enhanced services (e.g. greater convenience). In turn, customers may consider that such a disruptive innovation is altering the established conditions of the service-provider relationship. Based on attribution theory, this research explores how customers' attributions about the firm motivations to implement service robots (i.e. cost reduction and service enhancement) are affecting customers' intentions to use and recommend this innovation. Following previous research on robot's acceptance, our research framework analyzes how these attributions may be shaped by customers' perceptions of robot's humanlikeness and their affinity with the robot. Structural equation modelling is used to analyze data collected from 517 customers evaluating service robots in the hospitality industry; results show that attributions mediate the relationships between affinity toward the robot and customer behavioral intentions to use and recommend service robots. Specifically, customer's affinity toward the service robot positively affects service improvement attribution, which in turn has a positive influence on customer behavioral intentions. In contrast, affinity negatively affects cost reduction attribution, which in turn has a negative effect on behavioral intentions. Finally, human-likeness has a positive influence on affinity. This research provides practitioners with empirical evidence and guidance about the introduction of service robots and its relational implications in hospitality and tourism industries. Theoretical advances and future research avenues are also discussed.
\end{abstract}

Keywords Service robots · Human-likeness · Affinity $\cdot$ Customer attributions $\cdot$ Customer behavioral intentions $\cdot$ Hospitality industry

JEL classification M31 $\cdot \mathrm{L} 83 \cdot \mathrm{O} 32$

This article is part of the Topical Collection on Artificial Intelligence (AI) and Robotics in Travel, Tourism and Leisure

Responsible Editor: Ulrike Gretzel

Carlos Flavián

cflavian@unizar.es

Daniel Belanche

belan@unizar.es

Luis V. Casaló

lcasalo@unizar.es

1 Faculty of Economy and Business, University of Zaragoza, Gran Vía 2, 50.005, Zaragoza, Spain

2 Faculty of Business and Public Management, University of Zaragoza, Plaza Constitución s/n, 22.001, Huesca, Spain

\section{Introduction}

Robots are replacing employees in many tasks (Huang and Rust 2018; Hofmann et al. 2020). Indeed, sales of service robots for professional and personal use are growing at annual rates greater than 30\% (International Federation of Robotics 2018). Robotic applications are widely employed in manufacturing, military forces, medicine, home-care services and are increasingly common in hospitality and tourism (Murphy et al. 2017). Although some of these robots perform basic and routine tasks in hotels and restaurants (e.g. robotic floor cleaners [Murphy et al. 2017]), a growing number of them are performing more advanced frontline tasks that involve engaging customers at the social level (e.g. talking, serving food [Belanche et al. 2020a]). SoftBank Robotics, a leading service robot manufacturer, have sold more than 
25,000 robots like Pepper or its little brother Nao all over the world. From India to the US, automated agents as Pepper or Relay are already performing concierge and waiter tasks in hotels and restaurants (Mende et al. 2019). As one of the latest advances in smart technologies with a disruptive nature, these robots are reshaping frontline services and the way they are managed (Gretzel et al. 2015; van Doorn et al. 2017).

Due to the rise of service robots, scholars have started to delve into this emerging field. However, most of the existing research about frontline robots is theoretical (e.g. Huang and Rust 2018; van Doorn et al. 2017; Wirtz et al. 2018; Belanche et al. 2020b), also in hospitality and tourism industries (e.g. Murphy et al. 2019; Tung and Au 2018), which provides little guidance for decision management. Indeed, a recent literature review by Ivanov et al. (2019) revealed that most of the publications on robot's implementation in hospitality and tourism had a conceptual or descriptive nature. Interestingly, they also found that most of the analyzed papers adopted a supply-side, with only one fifth of the studies focusing on the customer side (Ivanov et al. 2019). Therefore, there is little evidence about the impact of robotics introduction on the customer-provider relationship.

One of the principal reasons for these companies to introduce service robots is to reduce their costs and increase their efficiency (Ivanov and Webster 2018). This is the case of waiter robots implemented in Asian and Western countries, which have an average price around 6000 USD, below the average yearly salary of hospitality workers in China, and that deliver between $50 \%$ and $100 \%$ more meals per day than a human employee (Hospitality and Marketing News 2019). Another frequent reason for implementing service robots in to enhance customers' hospitality experience, that is providing extra benefits such as welcoming customers, improving service consistency or reducing waiting times ( $\mathrm{Lu}$ et al. 2019; Qiu et al. 2020). Indeed, to achieve a successful introduction, not only companies but also customers need to be ready and willing to accept such innovation (Ivanov and Webster 2018). In this regard, previous research identified that the levels of robot human-likeness and user-robot affinity play a crucial role for their acceptance among customers of hospitality and tourism services (Murphy et al. 2019; Qiu et al. 2020). In addition, as far as service robots represent a disrupting innovation (Belanche et al. 2020a), customers may perceive that the firm is altering the established conditions of the service provision, thus leading to customers' psychological attributions (i.e. inferring the service provider reasons for introducing the innovation) and affecting the customer-provider relationship (Choi and Cai 2016; Nijssen et al. 2016).

To shed some light on this emerging but underdeveloped field of research, we propose a research framework that help better understand customers' decision to use and recommend service robots. We integrate literatures on customers' perceptions about robots and customers' reactions toward the introduction of service innovations. Based on attribution theory (Heider 1958; Kelley 1973), we propose that facing a disrupting technology such as a service robot increases customers' inferences about the reasons motivating its introduction by the firm. Following previous research on customers' attributions toward self-service technology introduction (Nijssen et al. 2016), we propose that customers attribute service enhancement or cost reduction as the principal firm motivations to introduce service robots. From a customerprovider relational perspective, service enhancement attributions increase customer's intention to use and recommend the service robots, whereas cost reduction attributions diminish these customer's behavioral intentions. Thus, our research does not focus on the actual motivations of the firm to introduce service robots, but on customers' inferences (i.e. dispositional attributions) about the firm motivations, since these customers' attributions have been proved to be affecting the customer-provider relationship in other settings (Nijssen et al. 2016). In addition, considering the existing knowledge on customers' perceptions about service robots, our research model argues that robot human-likeness increases customers' affinity with the automated agent (Mourey et al. 2017; Qiu et al. 2020), and that both factors increase customers' service enhancement attributions and reduce cost cutting attributions, as explained in our literature review section.

Based on responses collected from an international sample of 517 customers of hospitality and tourism services, our study contributes to expand the scarce knowledge about the impact of robot introduction on the customerprovider relationship. Due to the scarce empirical research on this topic, we aim to better understand customers' responses toward service robots implemented in these industries. We also contribute to the literature on customer's attributions in relation to firms' motivations for the introduction of service robots. This is a particularly suitable framework to be applied when dealing with customers' perceptions and thoughts about a newly launched service innovation, as it is the case of service robots. In this regard, our article combines two complementary fields or research: perceptions toward robots (i.e. human-likeness, affinity), and customer attributions about the firm (i.e. service enhancement and cost reduction motivations). In addition, considering the relevance of customers' recommendations for hospitality and tourism industries (Stienmetz et al. 2020; Casaló et al. 2010) and advancing from research focused exclusively on acceptance (Rosenthal-von der Püthen and Krämer, 2014; Lu et al. 2019), we analyze the relational impact of service robot introduction in terms of both customers' intentions to use and intentions to recommend the service robot to other potential customers. Finally, our research discusses the principal conclusions and findings derived from the results of our study. Implications for managers and customers are also provided 
with the aim of guiding future decisions about robot introduction in hospitality and tourism services.

\section{Literature review}

Technology-based initiatives are routinely incorporated in most companies' marketing strategies, but sometimes customers perceive them as unacceptable or harmful (Fullerton et al. 2017). This kind of innovations may alter the implicit psychological contract established by customers and service providers (Baeshen 2018), that is, the "individual's relational schema regarding the rules and conditions of the resource exchange between the organization and the person" (Guo et al. 2015, p. 4). From the standpoint of customers, their experience with a service robot may be different from those traditionally experienced with frontline employees, altering their psychological contract and increasing their awareness and thinking about the innovation (Qiu et al. 2020).

In this vein, attribution theory (Heider 1958; Kelley 1973) contributes to explain how individuals infer causal explanations in a social context, that is, identifying why someone did that (Nijssen et al. 2016). Differing form internal attributions (self-motivations), dispositional attributions focus on determining others' reason motivating their actions. Dispositional attributions have been successfully employed to comprehend how individuals infer firms' motivations to introduce service innovations. According to the multiple inference model (MIM) of attribution (Reeder et al. 2004), observers draw various inferences and attempt to integrate them into a coherent cognitive response. It is important to note that customer's dispositional attributions may be different from the actual reasons that are motivating the service provider to introduce the innovation (e.g. they may be exaggerated or based on heuristic cues [Allen and Leary 2010]). For instance, the introduction of a new distribution system is often perceived as motivated by increased convenience but also as an opportunistic and unfair allocation of gains by the service provider (Selviaridis 2016). In relation to self-service technology, which could be considered a precursor of service robots, customers attribute that firms may introduce this innovation to enhance the service offering, but they may also consider that this change could be motivated by cost cutting reasons (Nijssen et al. 2016). Therefore, depending on whether customers think that the implicit contract is fulfilled or violated by the service provider they would behave accordingly (e.g. psychological contract breach leads to greater dissatisfaction and lower loyalty [Baeshen 2018]).

Dispositional attributions may vary between customers and highly depends on individual's perceptions about the particular features of the innovation (Heywood and Norman 1988). In other words, the features of the technology being employed by the marketer to serve customers becomes the dominant attribute of the offering being judged (Fullerton et al. 2017). In this line, the uncanny valley theory (Mori 1970) proposes that individuals assess a robotic entity by focusing on two key features: their perception of robot's human-likeness and their feelings of affinity with the robot. Human-likeness could be defined as the extent to which the robot's physical appearance is similar to a human being (Seyama and Nagayama 2007). This term has been widely employed in literature about robot design and human-robot interaction (Walters et al. 2008). Human-likeness is also known as anthropomorphism or embodiment (Tung and Au 2018), considering that robots -as well as products or any kind or interfaces- may have certain anthropomorphic appearance, which usually leads to favorable evaluations by customers (Mourey et al. 2017).

In turn, according to previous research on human-robot interaction, affinity refers to a kind of human description of the robot as a "friendly" or "good feeling" entity (Maehara and Fujinami 2018). Rincon et al. (2016) describe affinity as the level of robot agreeableness perceived by a human; that is, the individual assumption that the other entity is being likeable, pleasant, and harmonious in relations with others (Graziano and Tobin, 2009). The original term in Japanese "shinwakan" was initially translated as familiarity (Mori 1970), but latter research concluded that the terms affinity or likeability are more appropriate than familiarity to describe this concept (Rosenthal-von der Püthen and Krämer, 2014).

Linking previous literature on robot acceptance and attribution theory towards service innovations, we propose an integrative research framework as detailed henceforth.

\section{Formulation of hypotheses}

\section{The relationship between human-likeness and per- ceived affinity}

According to Mori (1970), as robots appear more humanlike, our sense of their affinity increases. For instance, industrial robots in factories without faces or legs lack of resemblance to human begins, such as people hardly feel any affinity with them. In contrast, if robots start to have human-looking external form and features, people may start to feel attached to them (Mori et al. 2012). This effect could be explained by Simulation Theory (Gordon 1986), which assumes that individuals are able to understand other's mind by "simulating" another's situation in order to comprehend their mental state or emotion (Gordon 1986; Riek et al. 2009). As far as it is easier for people to empathize with the emotions and mental states of agents that appears similar to them or belong to the same group (Turner 1978), the human-like appearance of a robot would facilitate this process (Riek et al. 2009). This is based on the notion that, as robots resemble human, the positive feeling toward them increases due to the perceived 
similarity and empathetic connection with the robot (Sone 2017). In this sense, Lee et al. (2017) found that children develop high social affinity towards robots imitating children expression and appearance, suggesting an affective link between them. Another study found that people empathized more strongly with more human-like robots and less with mechanical-looking robots (Riek et al. 2009).

Previous research confirmed that a greater human-like appearance increases users' expectations about the cognitive capabilities of robots as if they could think, feel and behave as "humans" to certain extent (Gray and Wegner 2012; Hegel et al. 2008). In this line, customers' start to perceive robots as social entities depending on their level of human-likeness (Kim et al. 2013). Indeed, automated social presence (i.e. customer's perception of the robot as a social entity performing the service) is becoming a topic of increasing interest in service research, which assumes that the level of anthropomorphization determines the receptiveness and attractiveness of the service robot (van Doorn et al. 2017), also in hospitality and tourism industries (Murphy et al. 2019). For instance, customers' acceptance of a hotel service robot is higher and leads to more positive emotions when it has a more anthropomorphized appearance (Tussyadiah and Park 2018). In sum, human-likeness leads to a stronger sense of social inclusion and likeability (Mourey et al. 2017; Qiu et al. 2020), thus, increasing customer's affinity with the service robot. Consequently, we propose our first hypothesis:

\section{H1: Perceived human-likeness of robots in hospitality ser- vices has a positive effect on their perceived affinity.}

\section{The influence of human-likeness and perceived affin- ity on customers' attributions}

For service robots, human-likeness could be treated as an analogous factor to physical appearance (e.g. clothing) in frontline employees. Classical research on services marketing found that an appropriate physical appearance enhances customer perceptions of service quality (Gronroos 1984), firms' capabilities and control of the service encounter (Bitner 1990), process consistency (e.g. uniform clothing [Rafaeli 1993]) and overall satisfaction (Mayer et al. 2003). In addition, these physical features are interpreted by customers as a sign of the firm's dispositional attributions, that is to infer companies' motivations and procedures (Bitner 1990). Transferring these insights to a frontline robot context, human-likeness should lead to favorable attributions towards the company motivations to introduce such innovation. In this line, recent research on tourism and hospitality found that, compared to mechanic like alternatives, more anthropomorphic self-service technology reduces customers' blame attributions toward the firm's technology in case of service failure (Fan et al. 2019).
In addition, a higher level of robot human-likeness could be perceived as a greater investment by the company in "hightech" robotic agents with greater human qualities (Aggarwal and McGill 2007). Indeed, robots with increased human appearance are perceived as more sophisticated and impressive, incorporating the latest developments in the technological field (Roy and Sarkar 2016). Robots with human features tend to interact with customers following the same rules than human-to-human interactions, that is, performing tasks more closely to the traditional (and costly) service encounter (Tussyadiah and Park 2018). In contrast, low human-like robots may induce to cost reduction attribution because they resemble self-service technologies that highly depends on customer's effort and task making, altering the service provision (Meuter et al. 2005) and increasing the perceptions of the company shifting costs to the customer (Cunningham et al. 2009; Broadbent et al. 2009). Consequently:

H2: Perceived human-likeness of robots in hospitality services has a positive effect on service enhancement attribution.

H3: Perceived human-likeness of robots in hospitality services has a negative effect on cost reduction attribution.

Literature describing service encounters have found that employees' attractiveness and likeability increases customers' favorable perceptions in terms of aspects such as expertise and trustworthiness (Ahearne et al. 1999). Customers perceiving employees as attractive and likeable tend to attribute a higher service value and are more willing to tip them, spend more money and purchasing more expensive products (Jacob and Guéguen 2014; Otterbring et al. 2018). Customers affinity to a salesperson is also related to the employee cognitive and affective listening behaviors, as a kind of mutual recognition between both agents of the service encounter (Carlson 2016). Indeed, literature on sales management has widely covered how empathy and communication help building affinity between the salesperson and the customer (Smith 1998). In this sense, previous research found that more empathetic employees lead to customers' higher perceptions of service quality (Bitner et al. 1990). Thus, while a low level of affinity represents an impersonal technology driven interaction (Carlson 2016), a higher level of perceived affinity is linked to customers' expectations about the "knowledge, speed of response, breadth and depth of communication, and customization of the service offering" (Jones et al. 2005, p. 106). In the hospitality industry, advanced robots are able to recognize and process human feelings; designers also program them with facial expressions to actively respond to customers' affections, improving the communication and the perception of a human-orientation of the technology (Tung and Au 2018). Thus, especially in the case of a technology disruption, 
increased levels of affinity are positively evaluated by customers as a sign of firms' investment to keep the service standards instead of just reducing costs through technology (Carlson 2016). Therefore, we propose that:

H4: Perceived affinity of robots in hospitality services has a positive effect on service enhancement attribution.

H5: Perceived affinity of robots in hospitality services has a negative effect on cost reduction attribution.

\section{The influence of customers' attributions on customers' intentions}

Prior literature on service innovation identified that companies introduce technology mainly as an instrument to improve the service or to reduce the cost of the service provision (Bitner et al. 2002; Nijssen et al. 2016). These motivations have been also found to be the reasons for service robot introduction by firms in the hospitality industry (Qiu et al. 2020), which are focusing on the costs and benefits launching such innovation (Ivanov and Webster 2018; Ivanov et al. 2019).

Like self-service technology and chatbots, the introduction of service robots may result in a service enhancement in terms of increased convenience, reduction of the transaction times and quicker assistance to customer decision-making (Meuter et al. 2000; Ukpabi et al. 2019). When employed in hospitality, they also increase the service performance by improving the service consistency, providing more reliable information and minimizing errors in the service provision (Lu et al. 2019). Automation can also contribute to increase customer relationship management (CRM) by assisting employees and managers with information and resources to better serve the customer and to plan and organize accordingly (Kumar et al. 2019). For instance, some robot waiters greet customers when entering the restaurant and are able to call the customer by name or lead him or her to they preferred table based on the CRM information (Kabadayi et al. 2019).

Complementarily, firms introduce automated agents to reduce their costs (Kumar et al. 2019). Cost reduction is frequently associated to increased efficiency and job elimination (Meuter et al. 2000; Nijssen et al. 2016). Most of the service robots are designed to replace a human equivalent job (Belanche et al. 2020a). In particular, the hospitality sector introduces these kind of smart technological innovations to lower their cost and increase its efficiency (Gretzel et al. 2015; Ivanov and Webster 2018). For instance, robots and other smart devices are introduced in hotels to substitute guest-employees' interactions frequently described as costly, fallible and time-consuming (Kabadayi et al. 2019).

According to Nijssen et al. (2016), customers' dispositional attributions about the service provider motivations to introduce a technology focuses on service enhancement and cost reduction reasons, having positive and negative consequences for the customer-provider relationship respectively. Previous research on hospitality an tourism also indicate that customers own psychological processes (especially when making inferences about the positive and negative aspects of a service) play a central role in the customer-provider relationship (Choi and Cai 2016). Thus, as far as the introduction of a robot represent a disruptive innovation that could be perceived as fulfilling or violating the customer-provider psychological contract, we propose that these attributions lead to customer's behavioral intentions towards the company (Baeshen 2018). In particular, we hypothesize that customers' attributions of service enhancement motivation by the firm are interpreted as a relational investment (Nijssen et al. 2016) and increases customers' intentions to use and recommend the use of service robots. In turn, when customers attribute that a company implements robots in hospitality as a way to reduce costs, they would attribute a relational disinvestment (e.g. dismissing employees to maximize profit), which would reduce customers' intention to use and recommend such innovation. As a result, we propose the following hypotheses:

H6: Service enhancement attribution has a positive effect on customers' intention to use robots in hospitality services

H7: Service enhancement attribution has a positive effect on customers' intention to recommend robots in hospitality services

H8: Cost reduction attribution has a negative effect on customers' intention to use robots in hospitality services

H9: Cost reduction attribution has a negative effect on customers' intention to recommend robots in hospitality services

\section{The relationship between customers' intentions}

The use of a recently introduced technology by a critical mass of users is crucial to ensure its success on the medium and long terms (Belanche et al. 2012). In turn, customer recommendations are critical in hospitality and tourism (Alves et al. 2019), as far as customers' interpretation and sharing of their experiences in social media often become a stimuli influencing other customers and their journey mapping (Stienmetz et al. 2020). Customers with a higher intention to use a technology are more likely to recommend the technology to others (Oliveira et al. 2016). This loyalty based relationship occurs because behavioral intentions toward a recently introduced innovation in hospitality are based on users' positive perceptions about it, such that they tend to share this information with other people in order to spread its advantages and be seen in a positive light (Yang 2016). We thus propose our last hypothesis: 
H10: Customers' intention to use robots in hospitality services has a positive effect on the intention to recommend them.

In sum, the proposed model is summarized in Fig. 1.

\section{Method}

\section{Data collection}

A survey was used to collect the data for this study; specifically, participants comprised 517 international customers recruited via a market research company, which enabled us to obtain a diverse sample in terms of demographic characteristics such as gender ( $54.15 \%$ of participants are male), age ( $<25$ years $6.96 \%, 25-34$ years $38.68 \%, 35-44$ years $27.27 \%, 45-54$ years $15.09 \%, 55$ or more $11.99 \%$ ), education level (university studies $76.98 \%$, secondary school $21.28 \%$, primary school 1,74\%), employment situation (full-time job $58.03 \%$, part-time job $14.89 \%$, student $5.42 \%$, unemployed $7.35 \%$, retired or other $14.31 \%$ ) and country of origin (68.47\% of participants come from US, $22.63 \%$ from the UK and $8.90 \%$ from other countries). To develop the Web survey and make the most of this method, the study followed recommendations by Illum et al. (2010), such as keeping it short and guaranteeing the anonymity of participants.

Following recent methodology employed in service robots research (Belanche et al. 2020a; Mende et al. 2019), all participants were asked to read a general description of the context accompanied by a picture of the robotic agent. We focus on waiter robots operating in restaurants as a prototypical frontline service innovation in hospitality that is taking off in China and other countries around the world (Nguyen 2016; Hospitality and Marketing News 2019). The text reads "Imagine that you decide to go to a real well-known mid-class restaurant in your city that you have visited at least once. When you are at the restaurant, you notice that you are going to be served by a robot waiter. It has been recently introduced by the restaurant to perform waiter tasks such as greeting customers, taking orders and delivering orders to the tables". To increase the variability in the human-likeness perceptions $(\mathrm{M}=3.148, \mathrm{SD}=1.798$, in a 7 -point scale $)$, participants viewed, by random assignation, one of the twelve humanoid robots selected in a pretest with other group of 116 participants (from Savioke Relay as less human-like $[\mathrm{M}=1.703$; $\mathrm{SD}=1.000]$ to GeminoidDK as more human-like $[\mathrm{M}=$ $5.430 ; \mathrm{SD}=1.218])$. The use of pictures of waiter robots accompanied by a general description of the context in a hypothetic restaurant scenario is a standard practice in current research in the field (Belanche et al. 2020a; Mende et al. 2019). A similar procedure is employed in experimental and survey based studies for introducing hospitality service encounters where robots perform check-in tasks in hotels (Park 2020; Yu and Ngan 2019), especially when customers have to evaluate robots' human-likeness (Mende et al. 2019; Fan et al. 2019). In order to avoid bias due to brand reputation (MacKenzie et al. 1986), the restaurant and the robot were not linked to any specific firm. Next, respondents answered the questionnaire, including variables measuring their perceptions about and affinity with the robot, their dispositional attributions and behavioral intentions, as well as some basic demographic information. The scenario realism was checked with two questions borrowed from Belanche et al. (2020a) and Fan et al. (2019), "How realistic is the scenario?" (from 1- not at all realistic, to 7 - very realistic) and "To what extent do you consider that the scenario is believable? (from 1- not at all believable, to 7 - very believable). The results indicated the suitability of the scenario since the scale (Pearson $\rho=0.850$ ) provided a mean of $5.018(\mathrm{SD}=$ 1.386), a value that indicates that participants perceive the restaurant scenario as realistic and believable (Belanche

Fig. 1 Research model

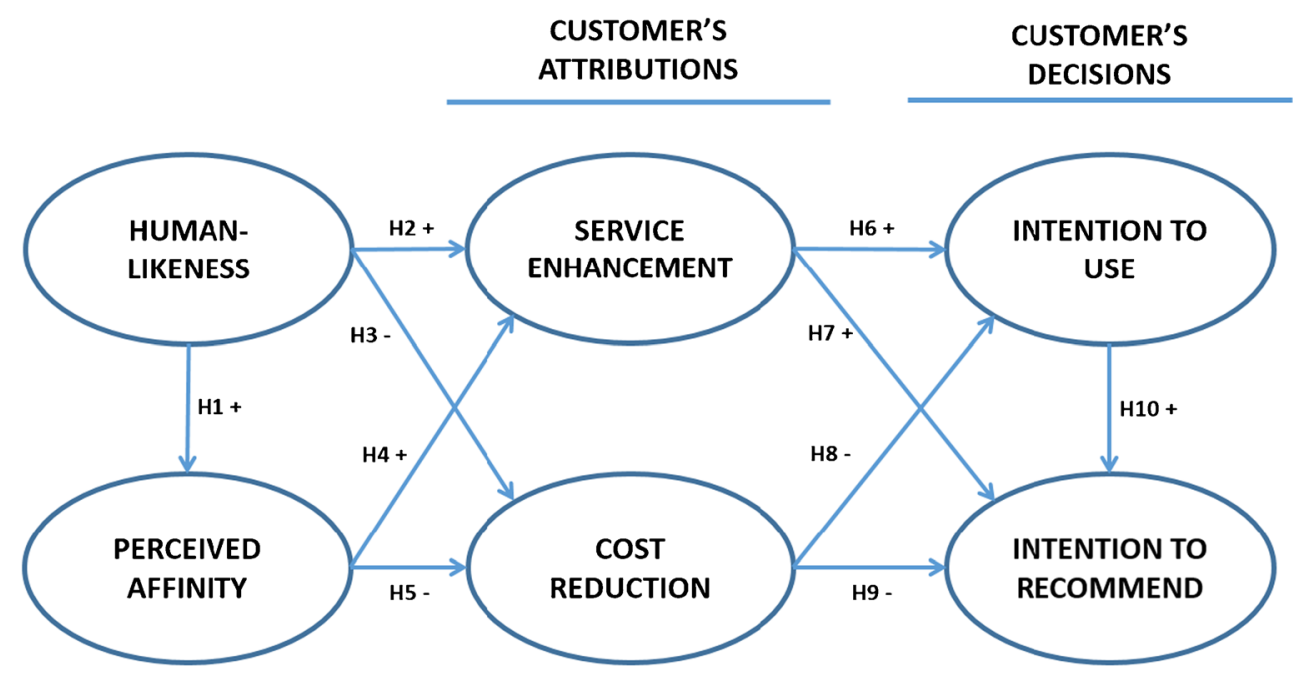


et al. 2020a; Fan et al. 2019). All scales (see Appendix Table 4) were based on self-reported measures and used seven-point Likert-type response formats, from 1 ("completely disagree") to 7 ("completely agree").

\section{Measurement validation}

The initial set of items proposed to measure the latent constructs came from an in-depth review of relevant literature pertaining to robot acceptance and customers' reactions towards technological innovations such as e-commerce and smart services. The measures were adapted from previous scales assessing perceived human-likeness and affinity (e.g. Rosenthal-von der Pütten and Krämer 2014; Gong and Nass, 2007), service enhancement and cost reduction perceptions (e.g. Nijssen et al. 2016), intention to use (e.g. Belanche et al. 2012; Yang and Jolly 2009) and intention to recommend (e.g. Ryu et al. 2012). The extensive review helped to ensure the content validity of the scales. Following Zaichkowsky (1985), the authors also asked a panel of experts about the degree to which they judged that the items were clearly representative of the targeted construct, in order to test for face validity. Items that prompted a high level of consensus among the experts were retained (Lichtenstein et al. 1990). Final measures can be seen in appendix Table 4 .

To confirm the dimensional structure of the scales, this study used confirmatory factor analysis and employed the statistical software EQS. 6.1. First, the factor loadings of the confirmatory model were verified and we eliminated those items that were not statistically significant (at 0.01 ) or higher than 0.5 (Steenkamp and Van Trijp 1991; Jöreskog and Sörbom 1993). Acceptable levels of convergence, R-square values, and model fit were finally obtained $\left(\chi^{2}=368.922\right.$, 120 df, $p<0.000$; Satorra-Bentler scaled chi-square $=$ 290.076, 120 df, $p=0.057$; NFI $=0.969$; NNFI $=0.977$; $\mathrm{CFI}=0.982 ; \mathrm{IFI}=0.982 ; \mathrm{RMSEA}=0.052 ; 90 \%$ confidence interval $[0.045,0.060])$. To assess construct reliability, this study also checked that values of the composite reliability (CR) indicator (Jöreskog 1971) were above the suggested minimum of 0.65 (Steenkamp and Geyskens 2006), as can be seen in Table 1. To further ensure convergent validity, it was verified that average variance extracted (AVE) values were greater than 0.5 (see Table 1) and converged on only one construct (Fornell and Larcker 1981). Finally, regarding discriminant validity, Table 1 shows that each construct shared more variance with its own measures than with the other constructs in the model (Fornell and Larcker 1981); that is, for each construct, the square root of the AVE is greater than correlations among constructs.

\section{Results}

\section{Hypotheses test}

The proposed hypotheses are tested using structural equation modeling, which basically "consists of a set of linear equations that simultaneously test two or more relationships among directly observable and/or unmeasured latent variables" (Shook et al. 2004, p. 397). This technique is selected as it enables to: (1) include the measurement error on the structural coefficients, which should not be ignored as any measure of a latent variable reflects not only a theoretical concept but also measurement error (Bagozzi et al. 1991), and (2) evaluate and interpret complex interrelated dependence relationships (e.g., Davcik 2014; Hair et al. 2010; MacKenzie 2001). In this respect, structural equation modeling is able to analyze simultaneously a series of relationships in which a dependent variable becomes an independent variable in subsequent relationships (for example, service enhancement and cost reduction perceptions in our case), while examining multiple dependent variables at the same time too (Jöreskog et al. 1999). More precisely, covariance-based structural equation modeling is employed because it is a confirmatory method that tends to replicate the existing covariation among measures (e.g., Fornell and Bookstein 1982; Hair et al. 2010).

Table 1 Convergent and discriminant validity of measures

\begin{tabular}{|c|c|c|c|c|c|c|c|c|}
\hline Relationship & CR & AVE & (1) & (2) & (3) & (4) & (5) & (6) \\
\hline Human-Likeness (1) & 0.806 & 0.687 & 0.829 & & & & & \\
\hline Perceived affinity (2) & 0.913 & 0.725 & $0.302 * * *$ & 0.851 & & & & \\
\hline Service enhancement attribution (3) & 0.884 & 0.719 & $0.170 * * *$ & $0.460 * * *$ & 0.848 & & & \\
\hline Cost reduction attribution (4) & 0.780 & 0.640 & -0.072 n.s. & $-0.113 * *$ & $-0.127 * *$ & 0.800 & & \\
\hline Intention to use (5) & 0.977 & 0.914 & $0.176^{* * * *}$ & $0.517 * * *$ & $0.604 * * *$ & $-0.182 * * *$ & 0.956 & \\
\hline Intention to recommend (6) & 0.973 & 0.923 & $0.228 * * *$ & $0.539 * * *$ & $0.574 * * *$ & $-0.129 * * *$ & $0.849 * * *$ & 0.961 \\
\hline
\end{tabular}

Notes: Bold numbers on the diagonal show the square root of the average variance extracted; numbers below the diagonal represent construct correlations. *** Correlations are significant at the .01 level; ** correlations are significant at the .05 level; n.s. correlations are non-significant 
Fig. 2 Structural equation model: standardized solution

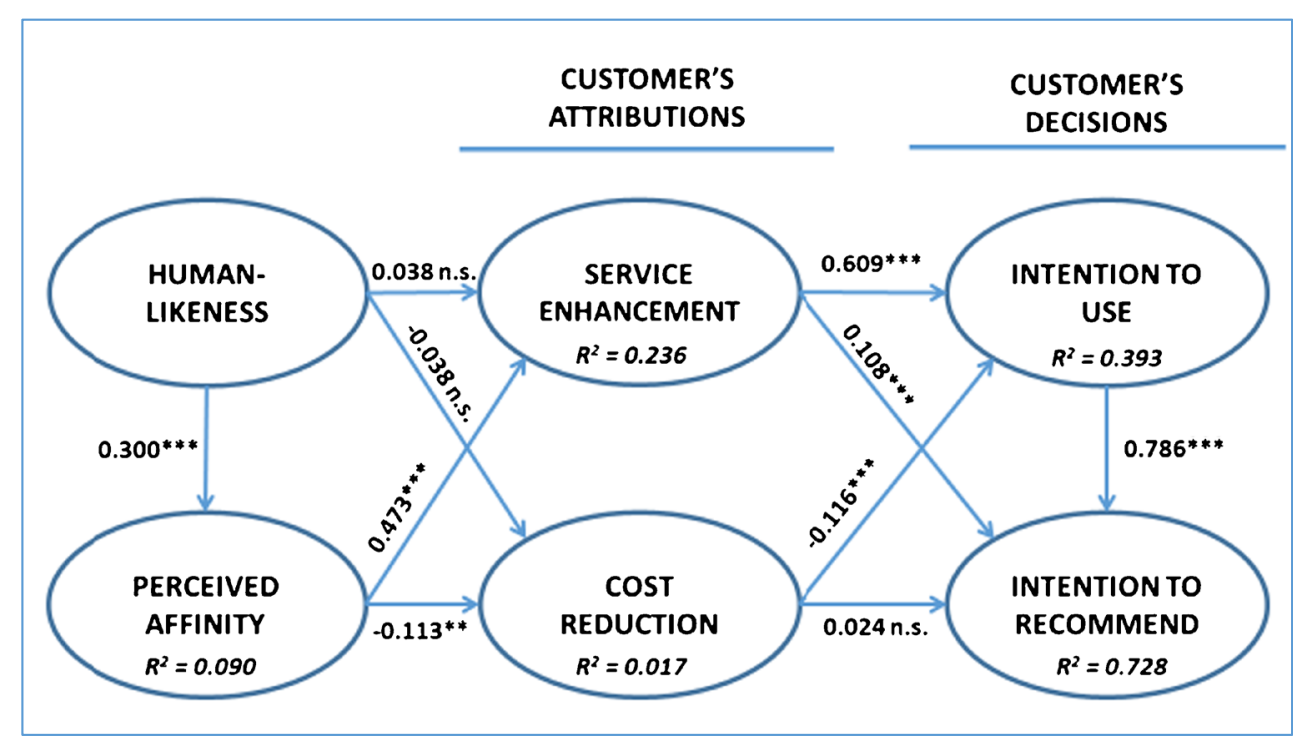

Standardized solution. Notes: $* * *$ coefficients are significant at the 01 level; ** coefficients are significant at the .05 level; n.s. coefficients are non-significant
Therefore, a structural equation model was developed (results are summarized in Fig. 2). The model fit showed acceptable values $\left(\chi^{2}=442.294,125 \mathrm{df}, p<\right.$ 0.000; Satorra-Bentler scaled $\chi^{2}=351.646,125 \mathrm{df}, p<$ $0.000 ; \mathrm{NFI}=0.963 ; \mathrm{NNFI}=0.970 ; \mathrm{CFI}=0.976 ; \quad \mathrm{IFI}=$ $0.976 ;$ RMSEA $=0.059 ; 90 \%$ confidence interval $[0.052,0.067])$.

First, regarding the relationship between the two variables considered in the uncanny valley theory, we observe that human-likeness of service robots has a positive influence on perceived affinity $(\gamma=0.300, p<0.01)$, which supports $\mathrm{H} 1$. Second, regarding the influence of these two variables on customers' attributions of service enhancement $(\gamma=0,038$, $p>0.1)$ and cost reduction $(\gamma=-0,038, p>0.1)$ are not affected by human-likeness. In turn, perceived affinity positively affects service enhancement $(\beta=0.473, p<0.01)$ and reduce cost reduction perceptions $(\beta=-0.113, p<0.05)$. Therefore, while $\mathrm{H} 2$ and $\mathrm{H} 3$ are not supported, $\mathrm{H} 4$ and $\mathrm{H} 5$ are confirmed. Third, regarding the influence customers' attributions on intentions, we first observe that service enhancement has a positive effect on both customers' intention to use robots in hospitality services $(\beta=0,609, p<0.01)$ and to recommend them $(\beta=0,108, p<0.01)$, confirming H6 and $\mathrm{H} 7$. However, cost reduction attributions has a negative effect on customers' intention to use waiter robots in hospitality services $(\beta=-0,116, p<0.01)$, and its influence on intention to recommend them is non-significant $(\beta=0,024, p>0.1)$, so that while H8 is confirmed, H9 is not supported. Finally, consumers' intentions are also related, as intention to use robots in hospitality services positively affects the intention to recommend them $(\beta=0.786, p<0.01)$, supporting H10.
In addition, the proposed framework implies some indirect effects of human-likeness and perceived affinity on customers' intentions (i.e., to use robots in hospitality services and to recommend them) via customers' attributions (i.e., service enhancements and cost reduction). Similarly, human-likeness indirectly affects customers' attributions (i.e., service enhancement and cost reduction perceptions) via perceived affinity. In this way, human-likeness exerts significant indirect effects on (1) service enhancement $(0.142, p<0.01)$, (2) cost reduction $(-0.034, p<0.05),(3)$ intention to use $(0.118, p<0.01)$ and $(4)$ intention to recommend $(0.111, p<0.01)$. Similarly, perceived affinity exerts significant indirect effects on (1) intention to use $(0.301, p<0.01)$ and $(2)$ intention to recommend $(0.285, p<$ $0.01)$. Finally, both customer's attributions, service enhancement $(0.479, p<0.01)$ and cost reduction $(-0.091, p<0.01)$, exert a significant indirect effect on intention to recommend through intention to use. Table 2 summarizes direct, indirect and total effects implied in the model.

All these relationships can largely explain our key dependent variables, customers' intention to use robots in hospitality services $\left(\mathrm{R}^{2}=0.393\right)$ and to recommend them $\left(\mathrm{R}^{2}=0.728\right)$.

\section{Post-hoc analysis: Direct effects of perceived human- likeness and affinity of frontline robots on customers' intentions}

For the shake of completeness, we conducted formal tests of mediation (Bagozzi and Dholakia 2006) to additionally check whether the direct effects of both perceived human-likeness and affinity of frontline robots 
Table 2 Summary of direct, indirect and total effects

\begin{tabular}{llll}
\hline Relationship & Direct effect & Indirect effect & Total effect \\
\hline Likeness $\rightarrow$ affinity (H1) & $0.300^{* * *}$ & - & $0.300^{* * *}$ \\
Likeness $\rightarrow$ service enhancement (H2) & 0.038 n.s. & $0.142^{* * *}$ & $0.180^{* * *}$ \\
Likeness $\rightarrow$ cost reduction (H3) & -0.038 n.s. & $-0.034^{* *}$ & -0.072 n.s. \\
Affinity $\rightarrow$ service enhancement (H4) & $0.473^{* * *}$ & - & $0.473^{* * *}$ \\
Affinity $\rightarrow$ cost reduction (H5) & $-0.113^{* *}$ & - & $-0.113^{* *}$ \\
Service enhancement $\rightarrow$ intention to use (H6) & $0.609^{* * *}$ & - & $0.609^{* * *}$ \\
Service enhancement $\rightarrow$ intention to recommend (H7) & $0.108^{* * *}$ & $0.479^{* * *}$ & $0.587^{* * *}$ \\
Cost reduction $\rightarrow$ intention to use (H8) & $-0.116^{* * *}$ & - & $-0.116^{* * *}$ \\
Cost reduction $\rightarrow$ intention to recommend (H9) & 0.024 n.s. & $-0.091^{* * *}$ & -0.067 n.s. \\
Intention to use $\rightarrow$ intention to recommend (H10) & $0.786^{* * *}$ & - & $0.786^{* * *}$ \\
Likeness $\rightarrow$ intention to use & - & $0.118^{* * *}$ & $0.118^{* * *}$ \\
Likeness $\rightarrow$ intention to recommend & - & $0.111^{* * *}$ & $0.111^{* * *}$ \\
Affinity $\rightarrow$ intention to use & - & $0.301^{* * *}$ & $0.301^{* * *}$ \\
Affinity $\rightarrow$ intention to recommend & - & $0.285^{* * *}$ & $0.285^{* * *}$ \\
\hline
\end{tabular}

Notes: *** coefficients are significant at the .01 level; ** coefficients are significant at the .05 level; n.s. coefficients are non-significant

on customers' intentions, which are not specified in the research model, might be significant. Table 3 shows a summary of results.

The first row of Table 3 shows the goodness-of-fit for the proposed model (M1), which provides the baseline for $\chi^{2}$ difference tests of direct effects from perceived humanlikeness or affinity to intentions (Bagozzi and Dholakia 2006). The second row in Table 3 (M2) adds to the proposed model a direct effect of perceived human-likeness on intention to use robots in hospitality services. Then, because M2 is nested in M1, we performed a $\chi^{2}$ difference test with one degree of freedom to determine whether this additional direct effect exists. Neither the additional effect in $\mathrm{M} 2$ is significant $(0.070 ; p>0.1)$ nor the $\chi^{2}$ difference $\left(\chi_{(1)}^{2}=3.583 ; p>0.1\right)$. We therefore conclude that the influence of perceived humanlikeness on intention to use is fully mediated by the relationships proposed in the research model (Kulviwat et al. 2009).
In M3, the effect of perceived human-likeness on customer intention to recommend is added. In this case, the additional effect, even small, is significant $(0.077 ; p<0.01)$ as well as the $\chi^{2}$ difference $\left(\chi_{(1)}^{2}=9.451 ; p<0.01\right)$. Therefore, the relationships proposed in the research model partially mediate the effect of perceived human-likeness on customer intention to recommend.

In turn, M4 includes the effect of perceived affinity on customer intention to use. In this case, both the additional effect $(0.301 ; p<0.01)$ and the $\chi^{2}$ difference $\left(\chi_{(1)}^{2}=\right.$ 49.783; $p<0.01)$ are significant. Similarly, M5 adds the effect of perceived affinity on customer intention to recommend, which is significant $(0.131 ; p<0.01)$ as well as the $\chi^{2}$ difference $\left(\chi_{(1)}^{2}=17.289 ; p<0.01\right)$. Therefore, the relationships proposed in the research model partially mediate the effects of perceived affinity of the frontline robot on both customers' intention to use robots in hospitality services and to recommend them.

Table 3 Summary of findings for formal tests of mediation

\begin{tabular}{llll}
\hline Model & Goodness-of-fit & $\chi^{2}$ Difference & Additional path \\
\hline $\begin{array}{l}\text { M1: Baseline model: } \\
\text { hypothesized paths (Fig. 2) }\end{array}$ & $\chi^{2}(125)=442.294 ; p<0.001$ & - & - \\
$\begin{array}{l}\text { M2*: M1 + perceived } \\
\text { human-likeness } \rightarrow \text { intention to use }\end{array}$ & $\chi^{2}(124)=438.711 ; \mathrm{p}<0.001$ & M1-M2: $\chi^{2}(1)=3.583 ; p>0.1$ & $0.070(\mathrm{p}>0.1)$ \\
$\begin{array}{l}\text { M3*: M1 + perceived } \\
\text { human-likeness } \rightarrow \text { intention } \\
\text { to recommend }\end{array}$ & $\chi^{2}(124)=432.843 ; \mathrm{p}<0.001$ & M1-M3: $\chi^{2}(1)=9.451 ; p<0.01$ & $0.077(\mathrm{p}<0.01)$ \\
$\begin{array}{l}\text { M4*: M1 + perceived } \\
\text { affinity } \rightarrow \text { intention to use }\end{array}$ & $\chi^{2}(124)=392.511 ; \mathrm{p}<0.001$ & M1-M4: $\chi^{2}(1)=49.783 ; \mathrm{p}<0.01$ & $0.301(\mathrm{p}<0.01)$ \\
$\begin{array}{l}\text { M5*: M1 + perceived } \\
\text { affinity } \rightarrow \text { intention to recommend }\end{array}$ & $\chi^{2}(124)=424.465 ; \mathrm{p}<0.001$ & M1-M5: $\chi^{2}(1)=17.289 ; \mathrm{p}<0.01$ & $0.131(\mathrm{p}<0.01)$ \\
\hline
\end{tabular}

Note: * In each model, the significance and sign of the remaining effects (i.e., the same that are included in the baseline model) does not differ from the reported in fig. 2 


\section{Discussion}

\section{Conclusions}

Following work intense industries such as manufacturing, military or home-care services, robotic agents have also arrived to hospitality and tourism services (Fan et al. 2019; Murphy et al. 2017). These frontline robots are performing concierge and waiter tasks requiring certain level of interaction with customers and that had been traditionally carried out by frontline employees (Huang and Rust 2018; Belanche et al. 2020a). Nevertheless, most of the scientific knowledge about this new research topic is purely theoretical or descriptive, with a scarce number or studies providing empirical evidence from the customer approach (Ivanov et al. 2019). In this emerging research field, our study contributes to shed some light on the impact of robot introduction on the customer-provider relationship. Based on previous insights from literatures on robot acceptance and customers' attributions about service innovations (Nijssen et al. 2016), we have analyzed to what extent customers' perceptions and thoughts about this innovation are affecting their decisions to use and recommend service robots being employed in hospitality and tourism industries.

The results of our study revealed that human-likeness, as a frequently researched feature of robot design, is less relevant than expected, and that customers' affinity with the robot is a greater predictor of robot introduction success in hospitality services. Particularly, human-likeness have a positive influence on affinity, which in turn plays a crucial role as a determinant of the rest of dependent variables in our model. This finding suggests that humanlikeness should be considered an instrumental variable to increase customers' perceptions of affinity (as a kind of familiarity and closer connection) with the service robot. This result is in line with previous research, which suggest that individuals tend to accept to a greater extent robots and other technological objects incorporating anthropomorphic features and that a more mechanical look leads to feelings of social exclusion (Mourey et al. 2017; Rosenthal-von der Pütten and Krämer 2014; Tussyadiah and Park 2018).

On the other hand, customers' affinity with the service robot plays a crucial role in determining their reactions toward the firm introducing such innovation. In particular, users perceiving greater levels of affinity with the robotic agents tend to think that the service provider introduced this technology to enhance the service provision, that is, taking a customer orientation or aiming to benefit the customer. In addition, customers increased affinity with the service robot also reduces their cost attributions, dissipating negative thoughts of robot introduction as a disinvestment (e.g. human unemployment [Huang and Rust 2018]) or as a strategy to shift the cost to the customer (like it sometimes happens with self-service technology [Cunningham et al. 2009; Broadbent et al. 2009]). In this regard, our research extends previous findings on customers' attributions about service technologies (Nijssen et al. 2016; Selviaridis 2016) and suggests that, contrary to previous technology lacking social features, service robots have the possibility of engaging customers at the social level (van Doorn et al. 2017), being customer's affinity with the robot the key factor to shape their psychological reactions towards this innovation.

Complementary, we found that service enhancement attributions are found to be an essential factor determining customers' intention to use and recommend robots in hospitality and tourism services. Following previous research analyzing the benefits of service technologies from the customer side (Meuter et al. 2000; Ukpabi et al. 2019), our study confirmed that customers considering that the firm introduces the innovation to improve the service provision to its customers (e.g. reducing transaction times) generate positive behavioral intentions toward the innovation. Indeed, service enhancement attributions by customers not only influence their intention to use service robots but also to recommend using it to other customers. This finding is particularly relevant in the context of our study, since customers recommendations (e.g. sharing the experience on social media platforms [Stienmetz et al. 2020]) are particularly helpful to gain customers in the hospitality and tourism industries (Casaló et al. 2010). Focusing on cost reduction attributions, our findings reveal that these thoughts are not particularly detrimental but that they reduce customers' intention to use service robots to some extent. This finding agrees with those of previous research on customers' attributions' about selfservice technology, indicating that the positive influence of service enhancement on loyalty surpass any detrimental perception of cost reduction (Nijssen et al. 2016).

A post-hoc analysis assessed the direct influence of humanlikeness and perceived affinity on customers' intentions to use robots in hospitality services and to recommend them. Results of this post-hoc analysis revealed that these direct influences are not very relevant. In particular, the influence of humanlikeness on intention to use is fully mediated by the variables in the model, whereas the remaining influence of human-likeness and of affinity on both use and recommendation intentions are partially mediated by the variables of the model. Thus, the post-hoc analysis contributed to understand the effects of customers' perceptions (i.e. robot's human-likeness, affinity) on customers' loyalty intentions (i.e. use and recommendation), by corroborating that customers' attributions fully or partially mediate these influences. 


\section{Implications for managers and customers}

Due to its efficiency and expansion in many service sectors, managers in hospitality and tourism industries are starting to consider the possibility of introducing service robots in their establishments. As far as these robotic entities perform more sophisticated frontline tasks at a lower cost than their human counterparts, service robots would become increasingly popular (Huang and Rust 2018). Nevertheless, customers support for this innovation is crucial to guarantee their success in the medium and long terms. The findings of our research suggest that the introduction of service robots should not only benefit the firm but it should have a clear benefit for customers in terms of service enhancement. According to the RAISA model (Ivanov and Webster 2019) the most direct way to incentive customer's adoption of robots in the hospitality and tourism industry is showing them that this innovation is beneficial for both companies (that can save costs) and customers (avoiding poor service quality). Thus, the introduction of service robots should not have negative impact upon service quality but should be implemented to enhance the overall service experience by adding customers' benefits to those traditionally established by frontline employees. In this regard, our research shows that customers intention to use and recommend the service is highly based on their attributions of the firm's motivations of service enhancement. That is, companies in the hospitality and tourism industries should make an effort to show that the introduction of service robots is not detrimental but positive for the customer experience.

In this line, our research found that focusing on customers' affinity with the robot is a crucial factor to increase service enhancement attributions. Previous literature on robot acceptance considered that humanlikeness is a cornerstone in the design of service robots (Fan et al. 2019. Rosenthal-von der Pütten and Krämer 2014). Nevertheless, our findings suggest that humanlikeness is just an instrumental variable, but that managers should focus on reaching high levels of customers' affinity with the robot. Like it happens with pets or toys, service robots should be able to engage customers at a social level (van Doorn et al. 2017). Customers curiosity and fun seeking may help them to start interacting and creating affinity with robot agents. Promoting robots as part of an attractive and enjoyable experience could be really useful to make customers interact with service robots (e.g. talk to them, use them to take orders). This finding also suggest that robot introduction could be particularly suitable in leisure and entertaining business where customers' amusement is paramount or in restaurants and hotels linked to such activities. Indeed, introducing the robots in such contexts and with a service enhancement orientation would be very helpful to increase its use but also to boost customers' recommendations in social media (e.g. taking and sharing photos).

\section{Further research and limitations}

In spite of these interesting contributions, this work has some limitations that suggest avenues for further research. First of all, in this study an international sample evaluated twelve humanoid robots in order to explain behavioral intentions as the main dependent variables. Even though previous research (Venkatesh and Davis, 2000) has confirmed that intention to use and actual use are habitually highly correlated in the case of volitional behaviors -as it is the case in the current study- and the fact that intentions help understand initial stages of the adoption process (e.g. Bhattacherjee, 2001), future research should develop a longitudinal field study that collects data about customers reactions towards frontline robots in the hospitality and tourism industries. In this regard, although the use of hypothetical scenarios is a common practice in literature on service robots (Park, 2020; Fan et al. 2019), it could be considered a limitation of the study. Thus, to increase the generalization of the findings, the research should be replicated as a field study in a restaurant that has already introduced service robots. Second, since individual factors are crucial to understand the application of theoretical models to specific situations (Sun and Zhang 2006), future studies could analyze the moderating role of individual characteristics, such as demographics (e.g., age, sex, etc.) or personality traits (e.g., technology readiness, need for social interaction, etc.). This way, it would be possible to evaluate how the proposed relationships might vary across customers. Third, the explained variance of affinity and cost reduction is low, suggesting that these variables could be affected by additional factors. In this regard, previous studies on service robots found that robot performance (Nijssen et al. 2016; Belanche et al. 2020a) and social influences (e.g. other customers' opinion, Belanche et al.

2019) may be also affecting customers' reactions towards robots. Finally, most participants in this research come from the UK and the US; therefore, future studies could replicate this study by incorporating other cultures (e.g. Asian, LatinAmerican, Jewish, etc.) to obtain a global understanding of how customers' attributions together with perceptions about service robots influence customer behavioral intentions in the hospitality industry. 


\section{Appendix 1. Measurement scales}

Table 4 Individuals were asked to rate from 1 (strongly disagree) to 7 (strongly agree) the following statements

\section{HUMAN-LIKENESS}

LIKENESS1 The appearance of the robot is very human-like
LIKENESS2

AFFINITY

AFFINITY1

AFFINITY 2

AFFINITY 3

AFFINITY 4

AFFINITY5

AFFINITY6

AFFINITY7

AFFINITY8
The appearance of the robot is very mechanical

I think that the robot is likable

I think that the robot is attractive

I think that the robot is familiar

I think that the robot is natural

I think that the robot is intelligent

I think that the robot is warm

I think that the robot is nice

I think that the robot is good

\section{SERVICE ENHANCEMENT ATTRIBUTION}

Why do you think the restaurant introduces a robot waiter? This is to...

$\begin{array}{ll}\text { SERV_ENH1 } & \text {...offer customers more options in service } \\ \text { SERV_ENH2 } & \text {...provide service easier and faster } \\ \text { SERV_ENH3 } & \ldots \text {..make ordering less a hassle } \\ \text { SERV_ENH4 } & \ldots \text {...make service more fun for their customers } \\ \text { SERV_ENH5 } & \text {...enhance customer service }\end{array}$

\section{COST REDUCTION ATTRIBUTION}

Why do you think the restaurant introduces a robot waiter? This is to...

$\begin{array}{ll}\text { COST_RED1 } & \ldots \text { lower their costs and increase their profits } \\ \text { COST_RED2 } & \ldots \text { let machines do the work } \\ \text { COST_RED3 } & \ldots \text { make even more money } \\ \text { COST_RED4 } & \ldots \text { increase their turnover even more } \\ \text { COST_RED5 } & \ldots \text { make more profits instead of serve customers } \\ \text { INTENTION TO USE ROBOTS } & \\ \text { INT_USE1 } & \text { I would like to come back to this restaurant in the future } \\ \text { INT_USE2 } & \text { I would consider revisiting this restaurant in the future } \\ \text { INT_USE3 } & \text { Given the chance, I intend to use this kind of robot service } \\ \text { INT_USE4 } & \text { I expect my use of robot service to continue in the future } \\ \text { INTENTION TO RECOMMEND } & \\ \text { INT_REC1 } & \text { I would recommend this restaurant to my friends or others } \\ \text { INT_REC2 } & \text { I would say positive things about this restaurant to others } \\ \text { INT_REC3 } & \text { I would encourage others to visit this restaurant }\end{array}$


Open Access This article is licensed under a Creative Commons Attribution 4.0 International License, which permits use, sharing, adaptation, distribution and reproduction in any medium or format, as long as you give appropriate credit to the original author(s) and the source, provide a link to the Creative Commons licence, and indicate if changes were made. The images or other third party material in this article are included in the article's Creative Commons licence, unless indicated otherwise in a credit line to the material. If material is not included in the article's Creative Commons licence and your intended use is not permitted by statutory regulation or exceeds the permitted use, you will need to obtain permission directly from the copyright holder. To view a copy of this licence, visit http://creativecommons.org/licenses/by/4.0/.

\section{References}

Aggarwal, P., \& McGill, A. L. (2007). Is that car smiling at me? Schema congruity as a basis for evaluating anthropomorphized products. Journal of Consumer Research, 34(4), 468-479. https://doi.org/10. $1086 / 518544$

Ahearne, M., Gruen, T. W., \& Jarvis, C. B. (1999). If looks could sell: Moderation and mediation of the attractiveness effect on salesperson performance. International Journal of Research in Marketing, 16(4), 269-284. https://doi.org/10.1016/S0167-8116(99)00014-2.

Allen, A. B., \& Leary, M. R. (2010). Reactions to others' selfish actions in the absence of tangible consequences. Basic and Applied Social Psychology, 32(1), 26-34. https://doi.org/10. 1080/01973530903539861.

Alves, H., Campón-Cerro, A. M., \& Hernández-Mogollón, J. M. (2019). Enhancing rural destinations' loyalty through relationship quality. Spanish Journal of Marketing-ESIC, 23(2), 185-204. https://doi. org/10.1108/SJME-09-2018-0041.

Baeshen, M. H. (2018). Antecedents and outcomes of psychological contract breach: Coping behaviour as a mediator of the effects of feelings of violation related to service outcomes (Doctoral dissertation, Cardiff University).

Bagozzi, R. P., \& Dholakia, U. M. (2006). Antecedents and purchase consequences of customer participation in small group brand communities. International Journal of Research in Marketing, 23(1), 45-61. https://doi.org/10.1016/j.ijresmar.2006.01.005.

Bagozzi, R. P., Yi, Y., \& Phillips, L. W. (1991). Assessing construct validity in organizational research. Administrative Science Quarterly, 36(3), 421-458. https://doi.org/10.2307/2393203.

Belanche Gracia, D., Casaló Ariño, L. V., \& Flavián Blanco, C. (2012). Understanding the influence of social information sources on egovernment adoption. Information Research, 17(39), 531. http:// InformationR.net/ir/17-3/paper531.html. Accessed June 12, 2020.

Belanche, D., Casaló, L. V., \& Flavián, C. (2019). Artificial Intelligence in FinTech: understanding robo-advisors adoption among customers. Industrial Management \& Data Systems, 119(7), 14111430. https://doi.org/10.1108/IMDS-08-2018-0368

Belanche, D. Casaló, L. V., Flavián, C., \& Schepers, J. (2020a). Robots or frontline employees? Exploring customers' attributions of responsibility and stability after service failure or success, Journal of Service Management, forthcoming.

Belanche, D., Casaló, L. V., Flavián, C., \& Schepers, J. (2020b). Service robot implementation: a theoretical framework and research agenda. The Service Industries Journal, 3-4, 203-225. https://doi.org/10. 1080/02642069.2019.1672666.

Bhattacherjee, A. (2001). Understanding information systems continuance: an expectation-confirmation model. MIS Quarterly, 25(3), 351-370. https://doi.org/10.2307/3250921.
Bitner, M. J. (1990). Evaluating service encounters: the effects of physical surroundings and employee responses. Journal of Marketing, 54(2), 69-82. https://doi.org/10.2307/1251871.

Bitner, M. J., Booms, B. H., \& Tetreault, M. S. (1990). The service encounter: diagnosing favorable and unfavorable incidents. Journal of Marketing, 54(1), 71-84. https://doi.org/10.2307/ 1252174.

Bitner, M. J., Ostrom, A. L., \& Meuter, M. L. (2002). Implementing successful self-services technologies. Academy of Management Executive, 16(4), 96-108. https://doi.org/10.5465/ame.2002. 8951333.

Broadbent, E., Stafford, R., \& MacDonald, B. (2009). Acceptance of healthcare robots for the older population: Review and future directions. International Journal of Social Robotics, 1(4), 319. https:// doi.org/10.1007/s12369-009-0030-6.

Carlson, S. (2016). Personal Selling and the Internet: Is the Trusted Advisor Role Obsolete?. In proceedings of the Charleston, SC Atlantic Marketing Association Conference. https:// digitalcommons.kennesaw.edu/ama_proceedings/2016/PROSLSSLSMGT-T13/3/ Accessed June 12, 2020.

Casaló, L. V., Flavián, C., \& Guinalíu, M. (2010). Determinants of the intention to participate in firm-hosted online travel communities and effects on consumer behavioral intentions. Tourism Management, 31(6), 898-911. https://doi.org/10.1016/j.tourman.2010.04.007.

Choi, S. H., \& Cai, L. A. (2016). Tourist causal attribution: Does loyalty matter? Journal of Travel \& Tourism Marketing, 33(9), 1337-1347. https://doi.org/10.1080/10548408.2015.1125823.

Cunningham, L. F., Young, C. E., \& Gerlach, J. (2009). A comparison of consumer views of traditional services and self-service technologies. Journal of Services Marketing, 23(1), 11-23. https://doi.org/10. 1108/08876040910933057.

Davcik, N. S. (2014). The use and misuse of structural equation modeling in management research. Journal of Advances in Management Research, 11(1), 47-81. https://doi.org/10.1108/JAMR-07-2013-0043.

Fan, A., Wu, L., Miao, L., \& Mattila, A. S. (2019). When does technology anthropomorphism help alleviate customer dissatisfaction after a service failure?-The moderating role of consumer technology selfefficacy and interdependent self-construal. Journal of Hospitality Marketing \& Management, 29(3), 269-290. https://doi.org/10. 1080/19368623.2019.1639095.

Fornell, C., \& Larcker, D. (1981). Evaluating structural equation models with unobserved variables and measurement error. Journal of Marketing Research, 18, 39-50. https://doi.org/10.1177/ 002224378101800104.

Fornell, C., \& Bookstein, F. (1982). Two structural Equation Models: LISREL and PLS Applied to Consumer Exit-Voice Theory. Journal of Marketing Research, 29(November), 440-452. https:// doi.org/10.1177/002224378201900406.

Fullerton, S., Brooksbank, R., \& Neale, L. (2017). Consumer perspectives on the ethics of an array of technology-based marketing strategies: an exploratory study. Asia Pacific Journal of Marketing and Logistics, 29(5), 1079-1096. https://doi.org/10.1108/APJML-092016-0179.

Gong, L., \& Nass, C. (2007). When a talking-face computer agent is halfhuman and half-humanoid: Human identity and consistency preference. Human Communication Research, 33(2), 163-193. https:// doi.org/10.1111/j.1468-2958.2007.00295.x.

Gordon, R. M. (1986). Folk psychology as simulation. Mind \& Language, 1(2), 158-171.

Gray, K., \& Wegner, D. M. (2012). Feeling robots and human zombies: Mind perception and the uncanny valley. Cognition, 125(1), 125130. https://doi.org/10.1111/j.1468-0017.1986.tb00324.x.

Graziano, W. G., \& Tobin, R. M. (2009). Agreeableness. In M. R. Leary \& R. H. Hoyle (Eds.), Handbook of individual differences in social behavior (pp. 46-61). The Guilford Press. https://doi.org/10.1037/ 0022-3514.50.1.212. 
Gretzel, U., Sigala, M., Xiang, Z., \& Koo, C. (2015). Smart tourism: foundations and developments. Electronic Markets, 25(3), 179188. https://doi.org/10.1007/s12525-015-0196-8.

Gronroos, C. (1984). A service quality model and its marketing implications. European Journal of Marketing, 18(4), 36-44. https://doi.org/ 10.1108/EUM0000000004784.

Guo, L., Gruen, T., \& Tang, C. (2015). Seeing relationships through the lens of psychological contracts: the structure of consumer service relationships. Journal of the Academy of Marketing Science, 45(3), 1-20. https://doi.org/10.1007/s11747-015-0462-5.

Hair, J., Black, W., Babin, B., \& Anderson, R. (2010). Multivariate data analysis, 7th ed. Prentice Hall. https://doi.org/10.1007/978-3-64204898-2 395.

Hegel, F., Krach, S., Kircher, T., Wrede, B., \& Sagerer, G. (2008). Understanding social robots: A user study on anthropomorphism. In Proceedings of the 17th IEEE International Symposium on Robot and Human Interactive Communication (pp. 574-579). ROMAN 2008. https://doi.org/10.1109/ROMAN.2008.4600728.

Heider, F. (1958). The psychology of interpersonal relations. New York: Wiley.

Heywood, G., \& Norman, P. (1988). Problems of educational innovation: the primary teacher's response to using the microcomputer. Journal of Computer Assisted Learning, 4(1), 34-43. https://doi.org/10. 1111/j.1365-2729.1988.tb00091.x.

Hofmann, P., Samp, C., \& Urbach, N. (2020). Robotic process automation. Electronic Markets, 30(1), 99-106. https://doi.org/10.1108/ BPMJ-12-2018-0380.

Hospitality and Marketing News (2019). Robot Waiters, it's happening now and coming to a restaurant near you soon. https://www. hospitalityandcateringnews.com/2019/09/robot-waiters-happeningnow-coming-restaurant-near-soon/. Accessed 12 June 2020.

Huang, M. H., \& Rust, R. T. (2018). Artificial intelligence in service. Journal of Service Research, 21(2), 155-172. https://doi.org/10. $1177 / 1094670517752459$

Illum, S. F., Ivanov, S. H., \& Liang, Y. (2010). Using virtual communities in tourism research. Tourism Management, 31, 335-340. https://doi. org/10.1016/j.tourman.2009.03.012.

International Federation of Robotics. (2018). World robotics report 2018. Press conference summary, Tokyo. https://ifr.org/free-downloads/. Accessed June 12, 2020.

Ivanov, S., \& Webster, C. (2018). Adoption of robots, artificial intelligence and service automation by travel, tourism and hospitality companies - a cost-benefit analysis. In Marinov, V., Vodenska, M., Assenova, M. \& Dogramadjieva E. (Eds.), Traditions and Innovations in Contemporary Tourism (pp. 190-203). Cambridge Scholars Publishing.

Ivanov, S., \& Webster, C. (2019). Economic Fundamentals of the Use of Robots, Artificial Intelligence, and Service Automation in Travel, Tourism, and Hospitality. Robots, Artificial Intelligence, and Service Automation in Travel, Tourism and Hospitality, Emerald Publishing Limited, 39-55. https://doi.org/10.1108/978-1-78756687-320191002.

Ivanov, S., Gretzel, U., Berezina, K., Sigala, M., \& Webster, C. (2019). Progress on robotics in hospitality and tourism: a review of the literature. Journal of Hospitality and Tourism Technology, 10(4), 489-521. https://doi.org/10.1108/JHTT-08-2018-0087.

Jacob, C., \& Guéguen, N. (2014). The effect of employees' clothing appearance on tipping. Journal of Foodservice Business Research, 17(5), 483-486. https://doi.org/10.1080/15378020.2014.967642.

Jones, E., Brown, S. P., Zoltners, A. A., \& Weitz, B. A. (2005). The changing environment of selling and sales management. The Journal of Personal Selling and Sales Management, 25(2), 105111. https://doi.org/10.1080/08853134.2005.10749052.

Jöreskog, K. (1971). Statistical analysis of sets of congeneric tests. Psychometrika, 36, 109-133. https://doi.org/10.1007/BF02291393.
Jöreskog, K., \& Sörbom, D. (1993). LISREL 8: Structural Equation Modeling with the SIMPLIS Command Language. Chicago, IL: Scientific Software International.

Jöreskog, K. G., Sörbom, D., du Toit, S., \& du Toit, M. (1999). LISREL 8: New Statistical Features. Chicago, IL: Scientific Software International

Kabadayi, S., Ali, F., Choi, H., Joosten, H., \& Lu, C. (2019). Smart service experience in hospitality and tourism services. Journal of Service Management, 30(3), 326-348. https://doi.org/10.1108/ JOSM-11-2018-0377.

Kelley, H. H. (1973). The process of causal attribution. American Psychologist, 28(1), 107-128.

Kim, K. J., Park, E., \& Sundar, S. S. (2013). Caregiving role in humanrobot interaction: A study of the mediating effects of perceived benefit and social presence. Computers in Human Behavior, 29(4), 1799-1806. https://doi.org/10.1016/j.chb.2013.02.009

Kulviwat, S., Bruner II, G. C., \& Al-Shuridah, O. (2009). The role of social influence on adoption of high tech innovations: The moderating effect of public/private consumption. Journal of Business Research, 62(7), 706-712. https://doi.org/10.1016/j.jbusres.2007. 04.014.

Kumar, V., Rajan, B., Venkatesan, R., \& Lecinski, J. (2019). Understanding the role of artificial intelligence in personalized engagement marketing. California Management Review, 61(4), 135155. https://doi.org/10.1177/0008125619859317.

Lee, J. J., Kim, D. W., \& Kang, B. Y. (2017). Esthetic interaction model of robot with human to develop social affinity. International Journal of Advanced Robotic Systems, 14(4), 1-16. https://doi.org/10.1177/ 1729881417722721

Lichtenstein, D. R., Netemeyer, R. G., \& Burton, S. (1990). Distinguishing coupon proneness from value consciousness: an acquisition-transaction utility theory perspective. Journal of Marketing, 54, 54-67. https://doi.org/10.2307/1251816.

Lu, L., Cai, R., \& Gursoy, D. (2019). Developing and validating a service robot integration willingness scale. International Journal of Hospitality Management, 80, 36-51. https://doi.org/10.1016/j. ijhm.2019.01.005.

MacKenzie, S. B., Lutz, R. J., \& Belch, G. E. (1986). The role of attitude toward the ad as a mediator of advertising effectiveness: a test of competing explanations. Journal of Marketing Research, 23(2), 130-143. https://doi.org/10.1177/002224378602300205.

Maehara, K., \& Fujinami, K. (2018). Investigating psychological Effects on Positional Relationships Between a Person and a HumanFollowing Robot. In 2018 IEEE 24th International Conference on Embedded and Real-Time Computing Systems and Applications (RTCSA) (pp. 242-243). IEEE. https://doi.org/10.1109/RTCSA. 2018.00041

Mayer, K. J., Bowen, J. T., \& Moulton, M. R. (2003). A proposed model of the descriptors of service process. Journal of Services Marketing, 17(6), 621-639. https://doi.org/10.1108/08876040310495645.

MacKenzie, S. (2001). Opportunities for Improving Consumer Research through Latent Variable Structural Equation Modeling. Journal of Consumer Research, 28(June), 159-166. https://doi.org/10.1086/ 321954.

Mende, M., Scott, M. L., van Doorn, J., Grewal, D., \& Shanks, I. (2019). Service robots rising: How humanoid robots influence service experiences and elicit compensatory consumer responses. Journal of Marketing Research, 56(4), 535-556. https://doi.org/10.1177/ 0022243718822827.

Meuter, M. L., Bitner, M. J., Ostrom, A. L., \& Brown, S. W. (2005). Choosing among alternative service delivery modes: An investigation of customer trial of self-service technologies. Journal of Marketing, 69(2), 61-83. https://doi.org/10.1509/jmkg.69.2.61. 60759.

Meuter, M. L., Ostrom, A. L., Roundtree, R. I., \& Bitner, M. J. (2000). Self-service technologies: understanding customer satisfaction with 
technology-based service encounters. Journal of Marketing, 64(3), 50-64. https://doi.org/10.1509/jmkg.64.3.50.18024.

Mori, M. (1970). The uncanny valley. Energy, 7(4), 33-35.

Mori, M., MacDorman, K. F., \& Kageki, N. (2012). The uncanny valley. IEEE Robotics and Automation Magazine, 19(2), 98-100. https:// doi.org/10.1109/MRA.2012.2192811.

Mourey, J. A., Olson, J. G., \& Yoon, C. (2017). Products as pals: Engaging with anthropomorphic products mitigates the effects of social exclusion. Journal of Consumer Research, 44(2), 414-431. https://doi.org/10.1093/jcr/ucx038.

Murphy, J., Gretzel, U., \& Pesonen, J. (2019). Marketing robot services in hospitality and tourism: the role of anthropomorphism. Journal of Travel \& Tourism Marketing, 36(7), 784-795. https://doi.org/10. 1080/10548408.2019.1571983.

Murphy, J., Hofacker, C., \& Gretzel, U. (2017). Dawning of the age of robots in hospitality and tourism: Challenges for teaching and research. European Journal of Tourism Research, 15(2017), 104 111.

Nguyen, R. (2016). Restaurants in China are replacing waiters with robots. Business Insider, July 26, 2016. https:/www.businessinsider. com/chinese-restaurant-robot-waiters-2016-7?international= true\&r=US\&IR=T. Accessed June 12, 2020.

Nijssen, E. J., Schepers, J. J., \& Belanche, D. (2016). Why did they do it? How customers' self-service technology introduction attributions affect the customer-provider relationship. Journal of Service Management, 27(3), 276-298. https://doi.org/10.1108/JOSM-082015-0233.

Oliveira, T., Thomas, M., Baptista, G., \& Campos, F. (2016). Mobile payment: Understanding the determinants of customer adoption and intention to recommend the technology. Computers in Human Behavior, 61, 404-414. https://doi.org/10.1016/j.chb.2016.03.030.

Otterbring, T., Ringler, C., Sirianni, N. J., \& Gustafsson, A. (2018). The Abercrombie \& Fitch effect: The impact of physical dominance on male customers' status-signaling consumption. Journal of Marketing Research, 55(1), 69-79. https://doi.org/10.1509/jmr.15.0247.

Park, S. (2020). Multifaceted trust in tourism service robots. Annals of Tourism Research, 81, 102888. https://doi.org/10.1016/j.annals. 2020.102888

Qiu, H., Li, M., Shu, B., \& Bai, B. (2020). Enhancing hospitality experience with service robots: The mediating role of rapport building. Journal of Hospitality Marketing \& Management, 29(3), 247-268. https://doi.org/10.1080/19368623.2019.1645073

Rafaeli, A. (1993). Dress and behavior of customer contact employees: a framework for analysis. In T. Swartz et al. (Eds.), Advances in Services Marketing and Management (Vol. 2). Greenwich, CT: JAI Press. https://doi.org/10.1177/109467050031005.

Reeder, G. D., Vonk, R., Ronk, M. J., Ham, J., \& Lawrence, M. (2004). Dispositional attribution: multiple inferences about motive-related traits. Journal of Personality and Social Psychology, 86(4), 530 544. https://doi.org/10.1037/0022-3514.86.4.530.

Riek, L. D., Rabinowitch, T. C., Chakrabarti, B., \& Robinson, P. (2009). How anthropomorphism affects empathy toward robots. In Proceedings of the 4th ACM/IEEE international conference on Human robot interaction (pp. 245-246). https://doi.org/10.1145/ 1514095.1514158

Rincon, J. A., Costa, A., Novais, P., Julian, V., \& Carrascosa, C. (2016, June). Detecting Social Emotions with a NAO robot. In International Conference on Practical Applications of Agents and Multi-Agent Systems (pp. 286-289). Springer, Cham. https://doi. org/10.1007/978-3-319-39324-7 32.

Rosenthal-von der Püthen, A. M., \& Krämer, N. C. (2014). How design characteristics of robots determine evaluation and uncanny valley related responses. Computers in Human Behavior, 36, 422-439. https://doi.org/10.1016/j.chb.2014.03.066.

Roy, R., \& Sarkar, M. B. (2016). Knowledge, firm boundaries, and innovation: Mitigating the incumbent's curse during radical technological change. Strategic Management Journal, 37(5), 835854. https://doi.org/10.1002/smj.2357.

Ryu, K., Lee, H., \& Kim, W. (2012). The influence of the quality of the physical environment, food, and service on restaurant image, customer perceived value, customer satisfaction, and behavioral intentions. International Journal of Contemporary Hospitality Management, 24(2), 200-223. https://doi.org/10.1108/09596111211206141.

Selviaridis, K. (2016). Who's to blame or praise? Performance attribution challenges in outsourced service provision in supply chains. Supply Chain Management: An International Journal, 21(5), 513-533. https://doi.org/10.1108/SCM-11-2015-0439.

Seyama, J. I., \& Nagayama, R. S. (2007). The uncanny valley: Effect of realism on the impression of artificial human faces. Presence: Teleoperators and virtual environments, 16(4), 337-351. https:// doi.org/10.1162/pres.16.4.337.

Shook, C. L., Ketchen Jr., D. J., Hult, G. T. M., \& Kacmar, K. M. (2004). An assessment of the use of structural equation modeling in strategic management research. Strategic Management Journal, 25(4), 397404. https://doi.org/10.1002/smj.385.

Smith, R. W. (1998). A theory of affinity building: Salespersons' perceptions of communication practices in developing relationships. (Doctoral Dissertation). Retrieved from ABI/INFORM Collection, ProQuest Dissertations Publishing, 9830240.

Sone, Y. (2017). Introduction: The Japanese Robot and Performance. In Japanese Robot Culture (pp. 1-36). New York: Palgrave Macmillan. https://doi.org/10.1057/978-1-137-52527-7_1.

Steenkamp, J. B. E., \& Geyskens, I. (2006). How country characteristics affect the perceived value of web sites. Journal of Marketing, 70(3), 136-150. https://doi.org/10.1509/jmkg.70.3.136

Steenkamp, J. B. E., \& Van Trijp, H. C. (1991). The use of LISREL in validating marketing constructs. International Journal of Research in marketing, 8(4), 283-299. https://doi.org/10.1016/0167-8116(91) 90027-5

Stienmetz, J., Kim, J. J., Xiang, Z., \& Fesenmaier, D. R. (2020). Managing the structure of tourism experiences: Foundations for tourism design. Journal of Destination Marketing \& Management, forthcoming. https://doi.org/10.1016/j.jdmm.2019.100408.

Sun, H., \& Zhang, P. (2006). The role of moderating factors in user technology acceptance. International Journal of Human-Computer Studies, 64(1), 53-78. https://doi.org/10.1016/j.ijhcs.2005.04.013.

Tung, V. W. S., \& Au, N. (2018). Exploring customer experiences with robotics in hospitality. International Journal of Contemporary Hospitality Management, 30(7), 2680-2697. https://doi.org/10. 1108/IJCHM-06-2017-0322.

Turner, J. C. (1978). Social comparison, similarity and ingroup favouritism. In H. Tajfel (Ed.), Differentiation between social groups: Studies in the social psychology of intergroup relations. Oxford: UK. Academic Press. https://doi.org/10.1002/ejsp.2420140211.

Tussyadiah, I. P., \& Park, S. (2018). Consumer evaluation of hotel service robots. In B. Stangl \& J. Pesonen (Eds.), Information and communication technologies in tourism 2018 (pp. 308-320). Cham, Switzerland: Springer. https://doi.org/10.1007/978-3-319-72923-7_24.

Ukpabi, D., Aslam, B., \& Karjaluoto, H. (2019). Chatbot Adoption in Tourism Services: A Conceptual Exploration. In S. Ivanov \& C. Webster (Eds.), Robots, Artificial Intelligence, and Service Automation in Travel, Tourism and Hospitality (pp. 105-121). Emerald Publishing Limited. https://doi.org/10.1108/978-1-78756687-320191006.

Van Doorn, J., Mende, M., Noble, S. M., Hulland, J., Ostrom, A. L., Grewal, D., et al. (2017). Domo arigato Mr. Roboto: emergence of automated social presence in organizational frontlines and customers' service experiences. Journal of Service Research, 20(1), 43-58. https://doi.org/10.1177/1094670516679272.

Venkatesh, V., \& Davis, F. (2000). A theoretical extension of the technology acceptance model: four longitudinal field studies. 
Management Science, 46, 186-204. https://doi.org/10.1287/mnsc. 46.2.186.11926.

Walters, M. L., Syrdal, D. S., Dautenhahn, K., Te Boekhorst, R., \& Koay, K. L. (2008). Avoiding the uncanny valley: robot appearance, personality and consistency of behavior in an attention-seeking home scenario for a robot companion. Autonomous Robots, 24(2), 159178. https://doi.org/10.1007/s10514-007-9058-3.

Wirtz, J., Patterson, P. G., Kunz, W. H., Gruber, T., Lu, V. N., Paluch, S., et al. (2018). Brave new world: service robots in the frontline. Journal of Service Management, 29(5), 907-931. https://doi.org/ 10.1108/JOSM-04-2018-0119.

Yang, F. X. (2016). Effects of Restaurant Satisfaction and Knowledge Sharing Motivation on eWOM Intentions. Journal of Hospitality \& Tourism Research, 41(1), 93-127. https://doi.org/10.1177/ 1096348013515918.
Yang, K., \& Jolly, L. D. (2009). The effects of consumer perceived value and subjective norm on mobile data service adoption between American and Korean consumers. Journal of Retailing and Consumer services, 16(6), 502-508. https://doi.org/10.1016/j. jretconser.2009.08.005.

Yu, C. E., \& Ngan, H. F. B. (2019). The power of head tilts: Gender and cultural differences of perceived human vs human-like robot smile in service. Tourism Review, 74(2), 428-442. https://doi.org/10. 1108/TR-07-2018-0097.

Zaichkowsky, J. L. (1985). Measuring the involvement construct. Journal of Consumer Research, 12, 341-352. https://doi.org/10. 1086/208520.

Publisher's note Springer Nature remains neutral with regard to jurisdictional claims in published maps and institutional affiliations. 